MACIEL, GM; FINZI, RR; MARRA, AWC; CARVALHO, FJ; NOGUEIRA, APO. 2018. Agronomic potential and selection of okra hybrids to obtain potential genitors. Horticultura Brasileira 36: 112-117. DOI - http://dx.doi.org/10.1590/S0102-053620180119

\title{
Agronomic potential and selection of okra hybrids to obtain potential genitors
}

\section{Gabriel M Maciel; Rafael R Finzi; Alexandre William C Marra; Fábio J Carvalho, Ana Paula O Nogueira}

Universidade Federal de Uberlândia (UFU), Monte Carmelo-MG, Brazil; gabrielmaciel@ufu.br; rafaelfinzi@hotmail.com; alexandre. agro16@gmail.com; fabiojanoni@ufu.br; ana812004@yahoo.com.br

\begin{abstract}
Evaluation of pre-commercial hybrids in a germplasm bank is essential for determining its commercial potential or its utility as a potential genitor in a breeding program. The objective of this study was to determine genetic divergence and per se behavior of 47 pre-commercial hybrids from okra germplasm bank of the Universidade Federal de Uberlândia. Precocity index (\%), number of fruits (fruits per plant), average fruit mass ( $\mathrm{g}$ ) and productivity (g per plant) were evaluated. Analysis of genetic divergence was performed by multivariate analysis using Mahalanobis distance $\left(D_{i i}^{2}\right)$ with different clustering methods (UPGMA and canonical analysis). The performance of hybrids was compared by Scott-Knott $(p=0.05)$. A significant genetic variability among okra hybrids was observed. UPGMA and canonical analysis grouped the hybrids similarly, being satisfactory to represent genetic divergence. Ten hybrids presented higher performance than the commercial hybrids. Among them, UFU-QB16 stood out as the most promising hybrid for being used as a potential parent in breeding programs after auto pollination.
\end{abstract}

Keywords: Abelmoschus esculentus, genetic variability, heterosis.

\section{RESUMO}

Potencial agronômico e seleção de híbridos de quiabeiro para obtenção de genitores potenciais

A avaliação de híbridos pré-comerciais em um banco de germoplasma é essencial para determinar seu potencial comercial ou sua utilidade como potenciais genitores em um programa de melhoramento. Assim, o objetivo deste trabalho foi verificar a divergência genética e o comportamento per se de 47 híbridos pré-comerciais pertencentes ao banco de germoplasma de quiabeiro da Universidade Federal de Uberlândia. Foi avaliado o índice de precocidade (\%), o número de frutos (frutos por planta), o peso médio do fruto $(\mathrm{g})$ e a produtividade (g por planta). A análise da divergência genética foi realizada por meio de técnicas multivariadas utilizando-se a distância generalizada de Mahalanobis $\left(D_{\mathrm{iii}}^{2}\right)$ e empregando-se diferentes métodos de agrupamento (UPGMA e Variáveis Canônicas). O desempenho dos híbridos foi comparado pelo teste de médias Scott-Knott ( $\mathrm{p}=$ $0,05)$. Houve significativa variabilidade genética entre os híbridos de quiabeiro. Os métodos UPGMA e Variáveis Canônicas agruparam os híbridos de forma semelhante, sendo satisfatórios para representar a divergência genética. Dez híbridos obtiveram desempenho superior aos híbridos comerciais. Dentre eles, o híbrido pré-comercial UFU-QB16 se destacou como o mais promissor, podendo também ser utilizado, após autofecundação, na obtenção de genitores potenciais em programas de melhoramento genético.

Palavras-chave: Abelmoschus esculentus, heterose, variabilidade genética.

Received on November 11, 2016; accepted on October 13, 2017

$\mathrm{O}$ $\mathrm{kra}$ (Abelmoschus esculentus) is a vegetable with high nutritional values and great socioeconomic importance in Brazil. It is predominantly cultivated by family farmers (Filgueira, 2013). Despite being largely cultivated by small producers, the possibility of fruit exportation (Mota et al., 2010) and the high commercial value (Sawadogo et al., 2006) are encouraging large producers and seed companies to invest in the okra production.

Most of plant breeders seek to obtain heterotic hybrids with high productivity allied to precocity in okra breeding programs (Mattedi et al.,
2015, Binalfew \& Alemu, 2016; Kumar \& Reddy, 2016a,b). Although hybrid seeds have a higher cost compared to open pollination seeds, the advantages provided by hybrid plants stimulate the cultivation, mainly due to the higher productivity, providing plant homogeneity and disease resistance.

The development of more productive genotypes depends on the genetic variability available in germplasm banks (Koundinya et al., 2013). It is possible to select higher plants in new segregating populations from the crossbreeding between divergent parents and develop more productive cultivars or lineages for exploration of the heterosis (Kumar \& Reddy, 2016b).

In this context, the adequate choice of the parents for a crossbreeding is essential, and may determine the success or economic return of an okra breeding program. The use of multivariate techniques to estimate genetic divergence among parents can be performed using methods based on agronomic, molecular and morphological characteristics. For quantitative traits the variability can be visualized with the use of dissimilarity measures like the generalized Mahalanobis distance $\left(\mathrm{D}_{\mathrm{ii}}^{2}\right)$, which considers the residual variances 
and covariances between the traits (Cruz et al., 2012).

The clustering methods and/ or graphic dispersion facilitate the visualization and interpretation of the genetic distances, grouping individuals to obtain homogeneity within and heterogeneity between subgroups. Among these methods, optimization and hierarchical methods are often used in okra breeding programs (Akotkar et al., 2010; Prakash \& Pitchaimuthu, 2010; Koundinya et al., 2013; Mattedi et al., 2015; Kumar \& Reddy, 2016a).

In okra, clustering methods are used to verify the general and specific ability of combining lineages to predict heterosis in hybrid crosses (Wammanda et al., 2010; Kishor et al., 2013; Kumar $\&$ Reddy, 2016b).Thus, the evaluation of genetic diversity in this stage helps in the selection of pre-commercial hybrids and in the distinction between them, allowing to reach potential parents in okra breeding programs, as well as the launch of hybrids with good agronomic traits, superior to the market hybrids and with divergence.

The aim of the study was to verify the genetic divergence and the per se behavior of pre-commercial hybrids of okra and to select potential parents to foment future breeding programs.

\section{MATERIAL AND METHODS}

The experiment was carried out in Jaguariúna-SP $\left(22^{\circ} 41^{\prime} \mathrm{S}, 47^{\circ} 00^{\prime} \mathrm{W}, 570\right.$ $\mathrm{m}$ altitude). The plants were cultivated in a dystrophic Red Latosol (Oxisol) soil with clay texture. The humid subtropical climate was classified as $\mathrm{Cfa}$ according to Köppen classification, with rainy and hot summers, and dry and cold winters. During the experiment, there was a total precipitation of $738 \mathrm{~mm}$. The maximum and minimum temperature were 17 and $39^{\circ} \mathrm{C}$, respectively.

The genetic material used consisted of 47 pre-commercial okra hybrids from 17 crossing inbred lines belonging to the germplasm bank of Universidade Federal de Uberlândia breeding program. Three commercial hybrids (Speedy, Esmeralda and Veloce) were used, totaling 50 treatments (hybrids).

Sowing was done in polystyrene trays with 200 cells on December 2015 . The seedlings were produced in a greenhouse covered with a 150 microns anti-UV plastic. 33 days after sowing, the seedlings were transplanted to the field. Before transplanting, the soil was previously prepared with two plowings and two sortings. Analysis and correction of the soil were performed according to the crop's need. The soil used on the experiment had the following chemical characteristics: $\mathrm{pH}(\mathrm{H} 2 \mathrm{O})=5.9$; available $\mathrm{P}=30.1 \mathrm{mg} \mathrm{dm}^{-3} ; \mathrm{K}+=85 \mathrm{mg} \mathrm{dm}^{-3}$; $\mathrm{Ca}+2=2.8 \mathrm{cmolc} \mathrm{dm}^{-3} ; \mathrm{Mg}+2=1.0$ cmolc dm ${ }^{-3} ; \mathrm{H}+\mathrm{Al}=3.40 \mathrm{cmolc} \mathrm{dm}^{-3}$; organic matter $=4.2 \mathrm{dag} \mathrm{kg}^{-1}$; Clay $=$ $30 \% ; \mathrm{Al}=0.0 \mathrm{cmolc} \mathrm{dm}^{-3} ; \mathrm{CEC}$ at $\mathrm{pH}$ $7.0=7.42 \mathrm{cmolc} \mathrm{dm}^{-3}$; base saturation of $\mathrm{CEC}$ at $\mathrm{pH} 7.0=54.0 \% ; \mathrm{Cu}=2.3$ $\mathrm{mg} \mathrm{dm}{ }^{-3} ; \mathrm{Zn}=8.6 \mathrm{mg} \mathrm{dm}^{-3}$ and $\mathrm{Mn}=$ $6.6 \mathrm{mg} \mathrm{dm}^{-3}$.During all the experiment conduction, cultural practices, insect, disease and weed management were performed as recommended for okra culture (Filgueira, 2013).

The experiment followed a randomized block design (RBD), with 50 treatments (hybrids) and two replications, totaling 100 plots. Each experimental plot was composed of ten plants spaced $0.4 \times 1.0 \mathrm{~m}$. In total, 1000 plants were used in the field, equivalent to 2.5 plants $\mathrm{m}^{-2}$.

The fruits were harvested at intervals of three days, totaling ten harvests. The fruits were harvested at the commercial point, with sizes between 10 and 14 centimeters. The following quantitative traits of economic interest were evaluated: Average fruit mass (g) obtained by the ratio between the total mass and the number of all fruits harvested from the plot; Productivity (g per plant) obtained by the ratio between the total mass of the harvested fruits and the number of plants in the plot; Number of fruits (fruit per plant) obtained by the ratio between the total number of fruits and the number of plants in the plot; and Precocity Index (\%) obtained by the ratio between the sum of the masses of all fruits produced in the first two harvests and the total mass of fruits, multiplied by 100 .

Quantitative data were submitted to analysis of variance, where the mean square sums were compared by $F$ test $(p=0.05)$ and the means compared by Scott-Knott test $(p=0.05)$. Then, multivariate analyzes were carried out to determine genetic dissimilarity among the hybrids, obtaining the dissimilarity matrix by the Mahalanobis generalized distance $\left(D_{i i}^{2}\right)$. The genetic divergence was represented by a dendrogram obtained by the hierarchical method Unweighted Pair-Group Method Using Arithmetic Averages (UPGMA) and by canonical analysis. The validation of the UPGMA clusters were determined by the cophenotype correlation coefficient (CCC), calculated by Mantel's test (1967); and for canonical analysis, genetic diversity was visualized through a cartesian graph (Cruz et al., 2012). The relative contribution of the quantitative traits was measured according to Singh's criterion (1981). All the obtained data were analyzed using software Genes v. 2015.5.0 (Cruz, 2013).

\section{RESULTS AND DISCUSSION}

The genetic dissimilarity among the 50 okra hybrids estimated by the Mahalanobis generalized distance $\left(D_{i i}^{2}\right)$, varied between 1.25 (UFU-QB08 and UFU-QB32) and 73934.22 (UFUQB16 and UFU-QB18), indicating high genetic diversity among the genotypes. Akotkar et al. (2010), Prakash \& Pitchaimuthu (2010), Kandasamy (2015) and Mattedi et al. (2015) reported mean values of $11.95 ; 35.57$; 128.70 and 136.48 , respectively, for the largest mean dissimilarity distances between intergroups of okra genotypes, based on Mahalanobis distance. This demonstrates the great breadth of genetic variability in the evaluated genotypes.

Cluster formation represented by UPGMA dendrogram (Figure 1) had expressed cophenotype correlation coefficient of $0.79(p<0.01)$. It can be stated that the dendrogram reproduced satisfactorily the information contained in the distance matrix and consequently in the cluster formation. The separation of the clusters was done with a cutline of $20 \%$, established where an abrupt change was visualized in the branches 
present in the dendrogram (Cruz et al., 2012).

The hybrids constituted three distinct clusters with a $20 \%$ cutline in UPGMA dendrogram. Group I was formed by $74 \%$ of the genotypes; Group II by the commercial hybrid Speedy and the pre-commercial hybrids UFU-QB38, UFU-QB43, UFU-QB13, UFU-QB20 and UFU-QB16; and group III by the

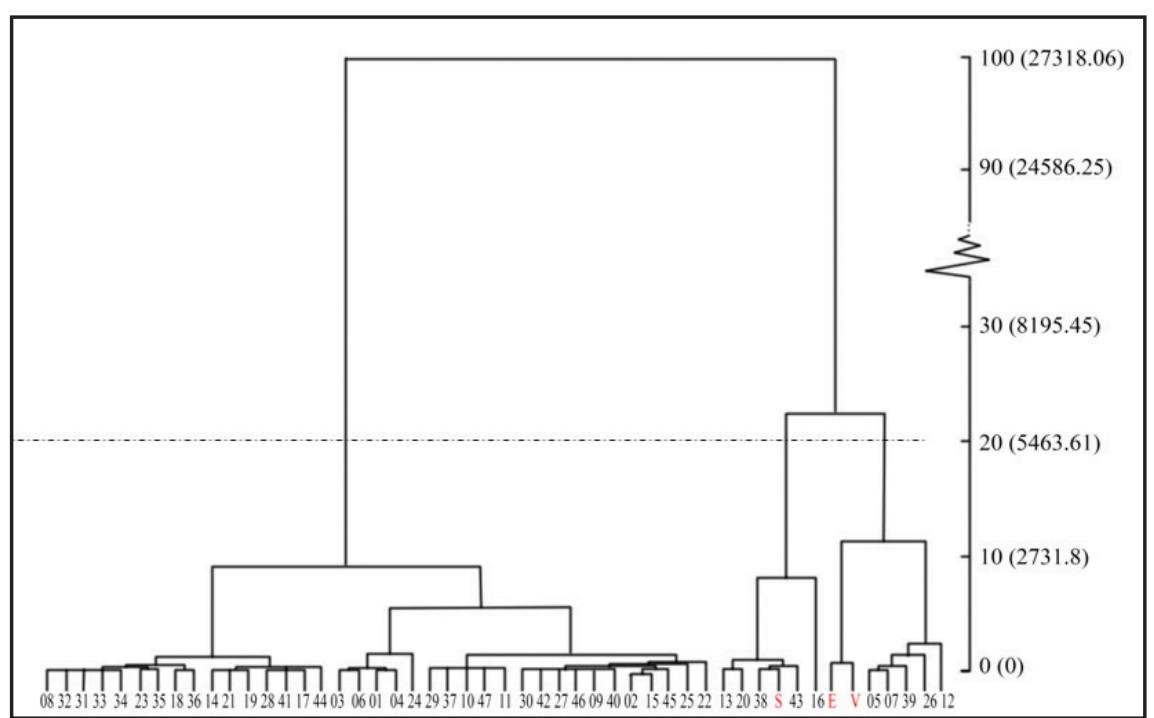

Figure 1. Dendrogram of the genetic divergence between 50 okra hybrids, achieved by the "UPGMA" method. The numerals indicate the pre-commercial hybrids UFU-QB; S, E, and V represent commercial hybrids Speedy, Esmeralda and Veloce, respectively. Monte Carmelo, UFU, 2016.

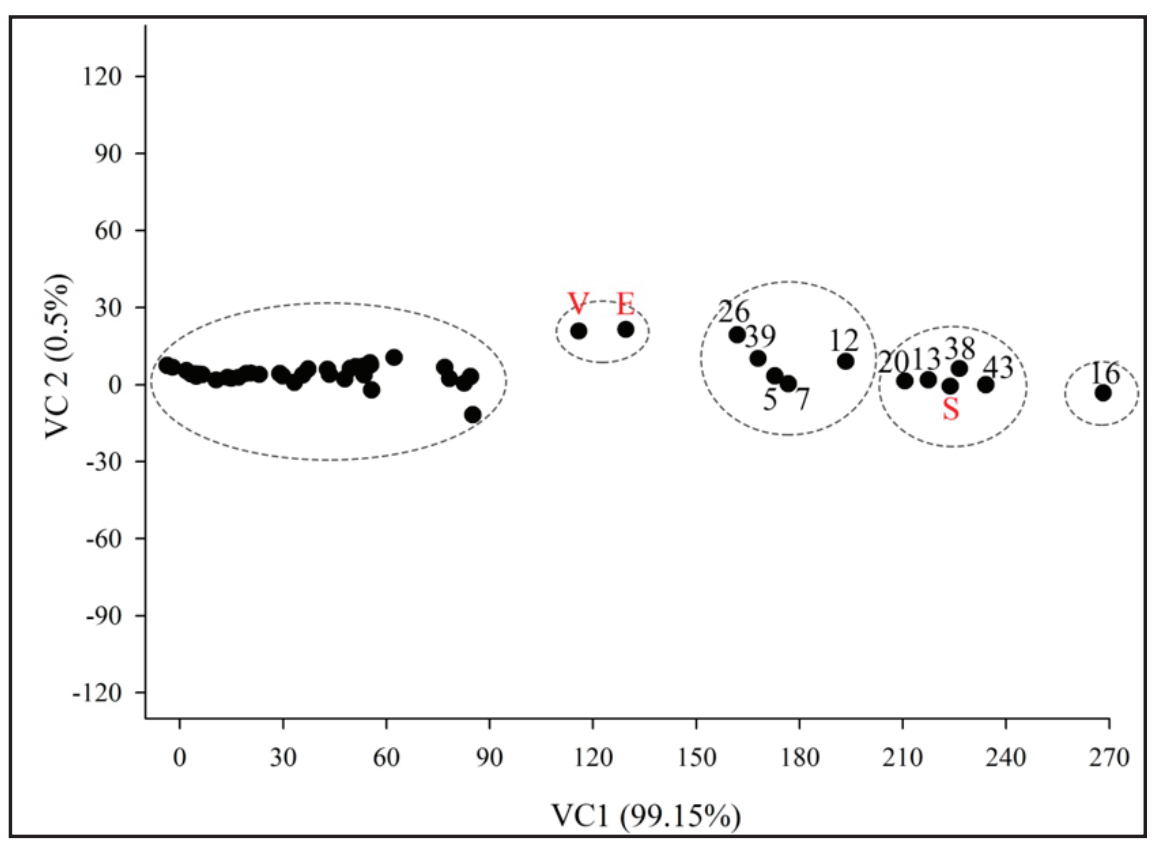

Figure 2. Graphic dispersion of the scores with two representative axes of canonical variables (VC1 and VC2). The numerals indicate the pre-commercial hybrids UFU-QB; S, E, and V represent comercial hybrids Speedy, Esmeralda and Veloce, respectively. Monte Carmelo, UFU, 2016. among okra genotypes successfully (Akotkar et al., 2010; Prakash \& Pitchaimuthu, 2010; Koundinya et al., 2013; Mattedi et al., 2015).

It was possible to identify five distinct groups by the graphic dispersion of the canonical analysis (Figure 2). Estimates of the corresponding eigenvalues of the first two canonical variables explained $99.65 \%$ of the total variation, where Canonical Variable 1 (VC 1) comprised $99.15 \%$ of the variability among the hybrids. Thus, it can be said that there was satisfactory description of genetic divergence. $74 \%$ of the hybrids were allocated to group I by the canonical analysis just like UPGMA method. In contrast, the differences between the methods consisted on the split of the commercial hybrids Esmeralda and Veloce, as well as of the pre-commercial hybrid UFU-QB16. The pre-commercial hybrid UFU-QB16 was separated from group IV and allocated alone; and commercial hybrids Esmeralda and Veloce were separated from group III.

According to Singh's criterion, the trait that contributed most for genetic divergence was productivity $(74.08 \%)$, followed by the number of fruits $(21.71 \%)$, precocity index $(3.42 \%)$, and average fruit mass $(0.79 \%)$. Unlike the results obtained, Akotkar et al. (2010) and Prakash \& Pitchaimuthu (2010) reported that the productivity and average fruit mass of different okra genotypes were determinant characters in approximately 2 and $8 \%$, respectively, of genetic variability. It is noteworthy that these authors evaluated more characteristics, which may have influenced the low relative contribution of productivity.

The relative contribution of the traits and the separation of genotypes into distinct groups help the breeders in the selection and conduction of breeding programs. However, the per se genotypes potential should also be considered as a selection criterion (Mattedi et al., 2015). The okra hybrids were contrasting with each other, considering their performance (Table 1). The number of fruits varied between 2 and 111; the precocity index between 3 and $75 \%$; the average fruit mass between 14 and $49 \mathrm{~g}$; and productivity between 
Table 1. Average productivity (PROD), number of fruits (NF), precocity index (PI) and Average fruitmass (AFM) of 50 okra hybrids. Monte Carmelo, UFU, 2016.

\begin{tabular}{|c|c|c|c|c|}
\hline Hybrids & PROD (g per plant) & NF (fruits per plant) & PI (\%) & AFM (g) \\
\hline UFU-QB16 & $3096.99 \mathrm{a}$ & $111.04 \mathrm{a}$ & $4.16 \mathrm{e}$ & $27.89 \mathrm{c}$ \\
\hline UFU-QB43 & $2672.01 \mathrm{~b}$ & $100.42 \mathrm{c}$ & $5.38 \mathrm{e}$ & $26.64 \mathrm{~d}$ \\
\hline UFU-QB38 & $2536.72 \mathrm{c}$ & $105.21 \mathrm{~b}$ & $6.85 \mathrm{e}$ & $24.11 \mathrm{~d}$ \\
\hline Speedy & $2555.42 \mathrm{c}$ & $95.00 \mathrm{~d}$ & $5.86 \mathrm{e}$ & $26.90 \mathrm{~d}$ \\
\hline UFU-QB13 & $2458.73 \mathrm{~d}$ & $95.63 \mathrm{~d}$ & $4.87 \mathrm{e}$ & $25.72 \mathrm{~d}$ \\
\hline UFU-QB20 & $2378.75 \mathrm{e}$ & $92.08 \mathrm{~d}$ & $3.78 \mathrm{e}$ & $25.83 \mathrm{~d}$ \\
\hline UFU-QB12 & $2123.68 \mathrm{f}$ & $94.58 \mathrm{~d}$ & $5.64 \mathrm{e}$ & $22.45 \mathrm{e}$ \\
\hline UFU-QB07 & $1992.77 \mathrm{~g}$ & $75.83 \mathrm{f}$ & $6.16 \mathrm{e}$ & $26.28 \mathrm{~d}$ \\
\hline UFU-QB05 & $1928.30 \mathrm{~h}$ & $78.13 \mathrm{f}$ & $7.29 \mathrm{e}$ & $24.68 \mathrm{~d}$ \\
\hline UFU-QB39 & $1810.52 \mathrm{i}$ & $85.21 \mathrm{e}$ & $3.64 \mathrm{e}$ & $21.25 \mathrm{e}$ \\
\hline UFU-QB26 & $1676.42 \mathrm{j}$ & $94.58 \mathrm{~d}$ & $6.79 \mathrm{e}$ & $17.72 \mathrm{f}$ \\
\hline Esmeralda & $1301.19 \mathrm{k}$ & $82.92 \mathrm{e}$ & $13.12 \mathrm{e}$ & $15.69 \mathrm{f}$ \\
\hline Veloce & 1134.061 & $76.46 \mathrm{f}$ & $7.93 \mathrm{e}$ & $14.83 \mathrm{f}$ \\
\hline UFU-QB06 & $885.76 \mathrm{~m}$ & $35.00 \mathrm{~h}$ & $7.77 \mathrm{e}$ & $25.31 \mathrm{~d}$ \\
\hline UFU-QB03 & $898.89 \mathrm{~m}$ & $39.17 \mathrm{~g}$ & $10.00 \mathrm{e}$ & $22.95 \mathrm{~d}$ \\
\hline UFU-QB24 & $931.13 \mathrm{~m}$ & 18.751 & $9.01 \mathrm{e}$ & $49.66 \mathrm{a}$ \\
\hline UFU-QB01 & $800.88 \mathrm{n}$ & $40.63 \mathrm{~g}$ & $13.49 \mathrm{e}$ & $19.74 \mathrm{e}$ \\
\hline UFU-QB04 & $834.43 n$ & $35.42 \mathrm{~h}$ & $10.65 \mathrm{e}$ & $23.60 \mathrm{~d}$ \\
\hline UFU-QB22 & 600.06 o & $39.58 \mathrm{~g}$ & $9.99 \mathrm{e}$ & $15.16 \mathrm{f}$ \\
\hline UFU-QB25 & $577.78 \mathrm{o}$ & 19.581 & $8.81 \mathrm{e}$ & $29.50 \mathrm{~d}$ \\
\hline UFU-QB42 & $549.13 p$ & $33.54 \mathrm{~h}$ & $16.37 \mathrm{~d}$ & $16.37 \mathrm{f}$ \\
\hline UFU-QB30 & $545.15 \mathrm{p}$ & $32.71 \mathrm{~h}$ & $11.54 \mathrm{e}$ & $16.67 \mathrm{f}$ \\
\hline UFU-QB40 & $553.90 \mathrm{p}$ & $26.25 \mathrm{j}$ & $16.23 \mathrm{~d}$ & $21.10 \mathrm{e}$ \\
\hline UFU-QB09 & $507.34 \mathrm{q}$ & $27.92 \mathrm{j}$ & $20.67 \mathrm{~d}$ & $18.17 \mathrm{f}$ \\
\hline UFU-QB27 & $521.27 \mathrm{q}$ & $31.04 \mathrm{i}$ & $11.49 \mathrm{e}$ & $16.79 \mathrm{f}$ \\
\hline UFU-QB45 & $493.42 \mathrm{q}$ & $21.88 \mathrm{k}$ & $15.79 \mathrm{~d}$ & $22.56 \mathrm{e}$ \\
\hline UFU-QB46 & $489.44 \mathrm{q}$ & $30.00 \mathrm{i}$ & $7.35 \mathrm{e}$ & $16.31 \mathrm{f}$ \\
\hline UFU-QB15 & $436.12 \mathrm{r}$ & $22.29 \mathrm{k}$ & $15.11 \mathrm{~d}$ & $19.56 \mathrm{e}$ \\
\hline UFU-QB02 & $417.81 \mathrm{r}$ & $25.00 \mathrm{j}$ & $13.60 \mathrm{e}$ & $16.71 \mathrm{f}$ \\
\hline UFU-QB11 & $337.83 \mathrm{~s}$ & $13.13 \mathrm{n}$ & $22.23 \mathrm{~d}$ & $25.74 \mathrm{c}$ \\
\hline UFU-QB37 & $370.06 \mathrm{~s}$ & $22.29 \mathrm{k}$ & $20.24 \mathrm{~d}$ & $16.60 \mathrm{f}$ \\
\hline UFU-QB29 & $350.17 \mathrm{~s}$ & 18.751 & $15.40 \mathrm{~d}$ & $18.68 \mathrm{f}$ \\
\hline UFU-QB10 & $296.05 \mathrm{t}$ & $16.04 \mathrm{~m}$ & $25.30 \mathrm{~d}$ & $18.46 \mathrm{f}$ \\
\hline UFU-QB47 & $306.40 \mathrm{t}$ & $15.21 \mathrm{~m}$ & $25.42 \mathrm{~d}$ & $20.15 \mathrm{e}$ \\
\hline UFU-QB14 & $245.12 \mathrm{u}$ & $11.46 \mathrm{n}$ & $47.67 \mathrm{c}$ & $21.39 \mathrm{e}$ \\
\hline UFU-QB17 & $210.90 \mathrm{u}$ & $6.46 \mathrm{o}$ & $62.50 \mathrm{~b}$ & $32.66 \mathrm{~b}$ \\
\hline UFU-QB19 & $262.63 \mathrm{u}$ & $12.08 \mathrm{n}$ & $42.21 \mathrm{c}$ & $21.73 \mathrm{e}$ \\
\hline UFU-QB21 & $242.73 \mathrm{u}$ & $10.21 \mathrm{n}$ & $55.54 \mathrm{c}$ & $23.78 \mathrm{~d}$ \\
\hline UFU-QB41 & $163.15 \mathrm{v}$ & 5.63 o & $53.25 \mathrm{c}$ & $29.00 \mathrm{c}$ \\
\hline UFU-QB28 & $171.10 \mathrm{v}$ & $5.42 \mathrm{o}$ & $54.28 \mathrm{c}$ & $31.59 \mathrm{~b}$ \\
\hline UFU-QB44 & $99.48 \times$ & $4.17 \mathrm{o}$ & $33.13 \mathrm{~d}$ & $23.88 \mathrm{~d}$ \\
\hline UFU-QB08 & $87.54 \mathrm{x}$ & $4.79 \mathrm{o}$ & $44.26 \mathrm{c}$ & $18.27 \mathrm{f}$ \\
\hline UFU-QB18 & $47.75 x$ & 3.96 o & $75.29 \mathrm{a}$ & $12.06 \mathrm{f}$ \\
\hline UFU-QB23 & $75.60 x$ & $2.71 \mathrm{o}$ & $63.40 \mathrm{~b}$ & $27.91 \mathrm{c}$ \\
\hline UFU-QB31 & $75.60 x$ & 3.960 & $51.51 \mathrm{c}$ & $19.10 \mathrm{e}$ \\
\hline UFU-QB32 & $79.58 \times$ & $4.54 \mathrm{o}$ & $45.17 \mathrm{c}$ & $17.52 \mathrm{f}$ \\
\hline UFU-QB33 & $59.69 x$ & $3.85 \mathrm{o}$ & $45.17 \mathrm{c}$ & $15.50 \mathrm{f}$ \\
\hline UFU-QB34 & $71.63 x$ & 3.96 o & $62.74 \mathrm{~b}$ & $18.10 \mathrm{f}$ \\
\hline UFU-QB35 & $63.67 x$ & $2.50 \mathrm{o}$ & $51.76 \mathrm{c}$ & $25.47 \mathrm{~d}$ \\
\hline UFU-QB36 & $55.71 \times$ & $3.50 \mathrm{o}$ & $75.29 \mathrm{a}$ & $15.92 \mathrm{f}$ \\
\hline $\mathrm{CV}(\%)$ & 2.31 & 3.49 & 21.83 & 6.93 \\
\hline
\end{tabular}

*Means followed by distinct letters in column, differ by Scott-Knott test at 0.05 significance. 


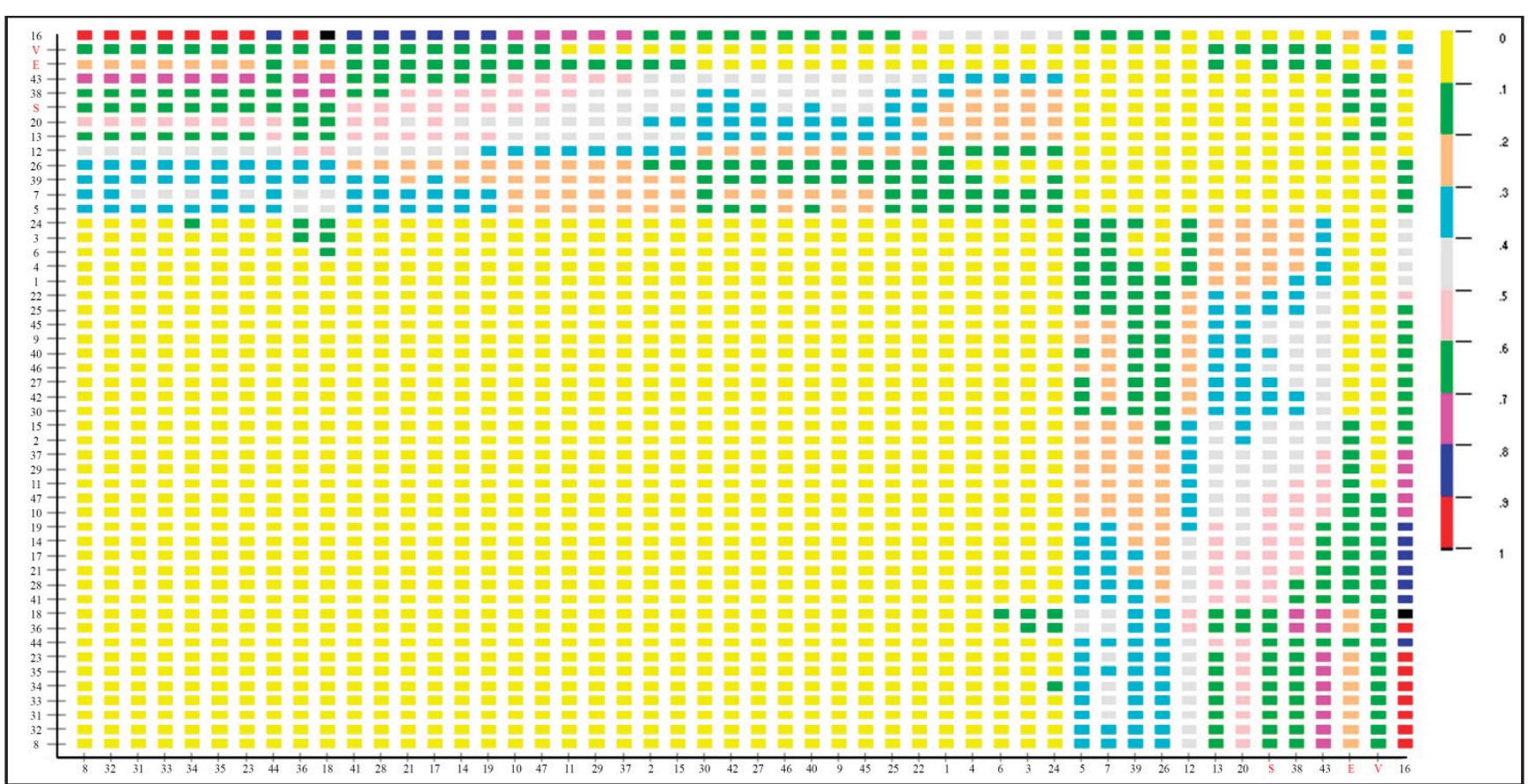

Figure 3. Graphical representation of dissimilarity based on the Mahalanobis distance ("D" _"ii'" ^"2" ) among 50 okra hybrids. The numerals indicate the pre-commercial hybrids UFU-QB; S, E, and V represents commercial hybrids Speedy, Esmeralda and Veloce, respectively. The colors present in the graph symbolize the variability from 0 to 1, where 1 represents the most genetic divergence. Monte Carmelo, UFU, 2016.

55 and 3096 g per plant.In general, earlier hybrids were less productive. Reddy et al. $(2012,2013)$ reported lower values for these traits in okra hybrids in India, mainly in relation to productivity, with values ranging from 202.46 to $345.28 \mathrm{~g}$ per plant (2012) and 244.67 to 414.74 g per plant (2013). On the other hand, okra productivity ranging from 194.11 to $1049.30 \mathrm{~g}$ per plant was found by Mattedi et al. (2015) in Brazil; and between 313.3 and 6698.7 g per plant by Binalfew \& Alemu (2016) in Ethiopia. These results demonstrate the great divergence that can exist in an okra bank germplasm, besides the difference of performance of genotypes in the diversified environments.

Among the 47 pre-commercial hybrids evaluated, ten were more productive (UFU-QB16, UFU-QB43, UFU-QB38, UFU-QB13, UFU-QB20, UFU-QB12, UFU-QB07, UFU-QB05, UFU-QB39 and UFU-QB26) than the commercial hybrids Esmeralda and Veloce. The hybrid UFU-QB16 was the most promising, presenting 17,58 and $63 \%$ more productivity in relation to the commercial hybrids Speedy, Esmeralda and Veloce, respectively. In general, UFU-QB16 presented the highest genetic distance compared to the other hybrids, as well as superior performance. The divergence of UFUQB16 represents the possibility of its insertion into breeding programs to obtain potential breeders for the extraction of promising lines. Thus, lineages extracted from this hybrid could provide heterosis in hybrid combinations with other divergent lineages.

A strategy widely used for the choice of parents by breeders is an exploration of lineages obtained from commercial hybrids segregation, with agronomic traits of interest. The higher divergence observed between the pre-commercial versus the commercial hybrids with desirable agronomic traits was between UFU-QB16 and Veloce (Figure 3). The genetic dissimilarity between the two hybrids was of 23867.56 , twice the average dissimilarity among all the hybrids (11804.88). It is noteworthy that both genotypes (UFU-QB16 and Veloce) were allocated in distinct groups by the UPGMA clustering method and canonical analysis, which reinforces this hypothesis.

It can be stated that pre-commercial hybrid UFU-QB16 has high productivity compared to the commercial hybrids and can be used as potential genitor in breeding programs. The multivariate analysis methods to study genetic diversity based on quantitative traits were similar to each other, complementing for the selection of genotypes and for the exploration of potential parents to foster okra breeding programs. In addition, it allowed the cluster of hybrids with similar or superior potential compared to the commercial hybrids, helping in the selection of genotypes with good agronomic performance.

\section{REFERENCES}

AKOTKAR, PK; DE, DK; PAL,AK. 2010. Genetic variability and Ddversity in okra (Abelmoschus esculentus L. Moench). Electronic Journal of Plant Breeding 1: 393-398.

BINALFEW, T;ALEMU, Y. 2016. Characterization of Okra (Abelmoschus esculentus (L.) Moench) Germplasms Collected from Western Ethiopia. International Journal of Research in Agriculture and Forestry 3: 11-17.

CRUZ, CD. 2013. GENES: a software package for analysis in experimental statistics and quantitative genetics. Acta Scientiarum 35: 271-276.

CRUZ, CD; REGAZZI, AJ; CARNEIRO, PCS. 2012. Modelos biométricos aplicados ao 
melhoramento genético. Viçosa: UFV. 514p.

FILGUEIRA, FAR. 2013. Novo manual de olericultura: agrotecnologia moderna na produção e comercialização de hortaliças. Viçosa: UFV. 421p.

KANDASAMY, R. 2015. Genetic divergence in okra [Abelmoschus esculentus L. (Moench)]. International Journal of Agricultural Sciences 11: $158-160$

KISHOR, DS; ARYA, K; DUGGI, S; MAGADUM, S; RAGHAVENDRA, NR; VENKATESHWARALU, C; REDDY, PS. 2013. Studies on heterosis for yield and yield contributing traits in okra (Abelmoschus esculentus (L.) Moench). Molecular Plant Breeding 4: 277-284.

KOUNDINYA, AVV; DHANKHAR, SK; YADAV, AC. 2013. Genetic variability and divergence in okra (Abelmoschus esculentus). Indian Journal of Agricultural Sciences 83: 97-100.

KUMAR, S; REDDY, MT. 2016a. Heterotic potential of single cross hybrids in okra (Abelmoschus esculentus L. Moench). Journal of Global Agriculture and Ecology 4: 45-66.

KUMAR, S; REDDY, MT. 2016b. Combining ability of inbred lines and half-diallel crosses for economic traits in okra (Abelmoschus esculentus (L.) Moench). Jordan Journal of Agricultural Sciences 12: 479-498.

MANTEL, N. 1967. The detection of disease clustering and a generalized regression approach. Cancer Research 27: 209-220.

MATTEDI, AP; LAURINDO, BS; SILVA, DJH; GOMES, CN; BHERING, LL; SOUZA, MA. 2015. Selection of okra parents based on performance and genetic divergence. African Journal of Biotechnology 14: 3044-3050.

MOTA, WF; FINGER, FL; CECON, PR; SILVA, DJH; CORREA, PC; FIRME, LP; MIZOBUTSI, GP. 2010. Conservação e qualidade pós-colheita de quiabo sob diferentes temperaturas e formas de armazenamento. Horticultura Brasileira 28: $12-18$.

PRAKASH, K; PITCHAIMUTHU, M. Nature and magnitude of genetic variability and diversity studies in okra (Abelmoschus esculentus L. Moench). 2010. Electronic Journal of Plant Breeding 1: 1426-1430.

REDDY, MT; HARIBABU, K; GANESH, M; BEGUM, H. Exploitation of heterosis in okra
(Abelmoschus esculentus (L.) Moench). 2013. International Journal of Agricultural and Food Research 2: 25-40.

REDDY, MT; HARIBABU, K; GANESH, M; BEGUM, H; REDDY, RSK. 2012. Exploitation of heterosis for growth, earliness and yield attributes in okra (Abelmoschus esculentus (L.) Moench). International Journal of Plant Breeding 6: 53-60.

SAWADOGO, M, BALMA, D, ZOMBRÉ, G. 2006. Expression de différents écotypes de gombo (Abelmoschus esculentus L.) au deficit hydrique intervenant pendant la boutonnisation et la floraison. BASE, Biotechnologie, Agronomie, Société, Environnement 10: 43-54.

SINGH, D. 1981. The relative importance of characters affecting genetic divergence. The Indian Journal of Genetic and Plant Breeding 41: 237-245.

WAMMANDA, DT; KADAMS, AM; JONAH, PM. 2010.Combining ability analysis and heterosis in a diallel cross of okra (Abelmoschus esculentus L. Moench). African Journal of Agricultural Research 5: 2108-2115. 